\title{
Evaluation of the Phagocitary Capacity of the Mononuclear System in an Experimental Model of Obstructive Jaundice Employing Tc- 99m Escherichia coli
}

\author{
Simone Odília Fernandes Diniz ${ }^{1 *}$, Alfredo José Afonso Barbosa ${ }^{2}$, Ivana Durval Araújo ${ }^{2}$, \\ David Lee Nelson ${ }^{1}$, Leonardo Augusto da Silva Machado ${ }^{2}$ and Valbert Nascimento \\ Cardoso $^{1}$ \\ ${ }^{1}$ Faculdade de Farmácia; ${ }^{2}$ Faculdade de Medicina; Universidade Federal de Minas Gerais; \\ simone@farmacia.ufmg.br; Belo Horizonte - MG - Brasil
}

\begin{abstract}
Infections and endotoxemia continue to be the principal causes of morbidity and mortality of patients with obstructions of the bile duct. The objective of the present work was the investigation of the phagocitary capacity of the mononuclear system in an experimental model of obstructive jaundice utilizing Tc-99m E.coli. The levels of aspartate aminotransferase (AST), alanine aminotransferase (ALT) and alkaline phosphatase (ALP) were significantly higher in jaundiced rats than in the control animals $(p<0.001)$. The liver of the jaundiced animals presented a significant reduction in Tc-99m E.coli uptake when compared to the controls $(p<0.001)$. The data also showed that there was a significant increase in the uptake of Tc-99m E.coli by the lungs of jaundiced rats $(p<0.01)$. The histological analyses of the liver of jaundiced rats showed an intense and diffuse proliferation of the bile ducts and an intensified polyploidy of the hepatocytes (mean volume $=843 \mu \mathrm{m}^{3}$ ), but no significant alterations were observed in the lungs of either group. This dates could contribute to a better understanding of the mechanisms involved in cases of bacteremia, renal failure and pulmonary dysfunction observed in clinical analyses of obstructive jaundice.
\end{abstract}

Key words: Mononuclear phagocyte system, Technetium-99m E. coli, obstructive jaundice

\section{INTRODUCTION}

The relationship of obstructive jaundice with septic complications and bacteremia is quite evident, this being the reason why studies that involve the removal of bacteria from the blood stream by the mononuclear phagocitary system has stimulated so much interest on the part of researchers (Katz et al., 1984; Ding et al., 1994). A cholestatic process caused by obstruction of the bile ducts that frequently occurs because of blockage of the choledochus by biliary calculous, stenosis or carcinoma of the pancreas and gall bladder characterizes obstructive jaundice. The rate of formation of bilirubin is normal, but the bilirubin cannot pass from the bile to the intestine (Guyton, 2002).

The determination of the activity of enzymes such as alanine aminotransferase (ALT), aspartate aminotransferase (AST) and alcaline phosphatase (ALP) are very important in the diagnosis of hepatobiliary diseases, higher values being observed in these cases. The aminotransferase enzymes are distributed among various tissues. AST can be found principally in the liver, heart and skeletal muscles. ALT has a similar 
distribution, but its concentration in the liver is lower than in other tissues. These are intracellular enzymes, and their activities increase in the plasma when lyses or cellular necrosis occurs. Alkaline phosphatase is also present principally in the liver, gall bladder, bile duct and bone marrow. Its activity increases principally when biliary tissues become obstructed, this being the basis for its clinical application (Sette et al., 1993; Zimmerman, 1995).

The mononuclear phagocyte system (MPS) is divided into stationary and mobile cells. The macrophages of the connective tissue (histiocytes) and the blood (monocytes) correspond to the mobile cells, while the macrophages of the liver

(Küpffer cells), spleen, lung and bone marrow correspond to the stationary cells (Athlin et al., 1991).

The strategically located macrophages of the liver and spleen correspond to approximately $85-95 \%$ of the total phagocitary capacity of the MPS. Among the principal functions of the macrophages are the defense against microorganisms, depuration of macromolecules and immunocomplexes, removal of old and damaged cells, removal of cellular fragments and inorganic material, inactivation of endotoxins, regulation of hematopoiesis, cooperation in the immune response and synthesis of biologically active products such as prostaglandins and monocines. The Küpffer cell is responsible for the removal of microorganisms from the portal blood system in those cases in which bacterial translocation occurs (Tanner et al., 1984).

Studies that involve the depuration of bacteria from the blood stream by the mononuclear phagocyte system have stimulated a great interest on the part of researchers. Investigations employing non-bacterial particles were performed to evaluate the phagocitary capacity of the MPS. However, conflicting results were obtained (Tanaka et al., 1985). Studies employing bacteria labeled with radioactive isotopes have also been performed to evaluate the MPS (DING et al., 1994; Katz et al., 1984; Megison et al., 1991). However, isotopes such as 125-iodine, 35-sulfur and 75-selenium were used in those studies. Therefore, the proposal of the present work was to investigate the phagocitary capacity of the mononuclear system in jaundiced and healthy rats utilizing Tc-99m E.coli.

\section{MATERIAL AND METHODS}

\section{Labelling of E.coli with ${ }^{99 \mathrm{~m}}$ Technetium}

E.coli was labeled with ${ }^{99 \mathrm{~m}}$ Technetium according to the procedure described by Diniz et al, 1999. Briefly, $2.0-\mathrm{mL}$ aliquots of the bacterial suspension were incubated at $37^{\circ} \mathrm{C}$ with $580 \mu \mathrm{M}$ stannous chloride, $\mathrm{pH} \mathrm{7.0,} \mathrm{for} 10$ minutes. Then, 15.0 to $74 \mathrm{MBq}$ of ${ }^{99 \mathrm{~m}}$ Tecnetium was added to each preparation and maintained at $37^{\circ} \mathrm{C}$ for another ten minutes. After centrifugation, $100-\mu \mathrm{L}$ aliquots of the supernatant and the precipitate were removed for determination of the labeling yield.

\section{Experimental model of obstructive jaundice}

Wistar rats, 250-350g, were anesthetized by intraperitoneal administration of a mixture of Rompun ${ }^{\circledR}(12.5 \mathrm{mg} / \mathrm{Kg})$ and Dopalen ${ }^{\circledR}(1.25$ $\mathrm{mg} / \mathrm{Kg}$ ). A central incision of approximately eight centimeters was made in the abdomen of the animals. The common bile duct (CBD) was ligated with a polyglycolic acid (Dexon ${ }^{\circledR}$ ) 4-0 and sectioned between the ligatures. The animals were maintained in cages during seven days with food and water ad libitum. The animals of the sham group (simulated surgery) were submitted to the same surgical stress.

\section{Mononuclear phagocitary system}

The 15 CBD group rats and 15 animals that suffered simulated surgery (sham) were used seven days after the respective surgeries to evaluate the MPS. The animals were anesthetized by intra-peritoneal administration of Rompun ${ }^{\circledR}$ $(12.5 \mathrm{mg} / \mathrm{Kg})$ e Dopalen ${ }^{\circledR} \quad(1.25 \mathrm{mg} / \mathrm{Kg})$. The abdomen was opened and $0.1 \mathrm{~mL}$ of Tc-99m E.coli $(0.32 \mathrm{MBq})$ was injected in a non-terminal branch of the superior mesenteric vein. The animals were sacrificed and liver, spleen and lungs were removed, washed, weighed and placed in tubes for determination of the radioactivity. The results were expressed as the percentage of Tc99m E.coli uptake by each organ and calculated according to the following equation:

$$
\% \text { uptake Tc-99m E.coli }=\frac{c p m \text { organ } / g \text { tissue }}{\Sigma \text { cpm organs/g tissue }} \times 100
$$

\section{Biochemical analyses}

The activities of the enzymes alkaline phosphatase (ALP), alanine aminotransferase (ALT) and 
aspartate aminotransferase (AST) were determined in the serum of 30 CBD $(n=15)$ and sham $(n=$ 15) rats, utilizing kits furnished by Química Básica Ltda (Quibasa).

\section{Histological analyses}

After sacrificing the CBD and sham animals, fragments of the lungs, liver and spleen were removed and fixed with $4 \%$ formaldehyde and coated with paraffin according to the normal procedure. Five-micrometer slices were obtained from each fragment and stained with hematoxylin e eosin (HE) for histological analyses. The liver slices were submitted to karyometry to calculate the average nuclear volume of the hepatocytes of both groups according to the procedure described by Barbosa (1978). A micrometric ocular and immersion optical microscopy were used for this purpose. A random selection of well-defined hepatocyte nuclei $(n=30)$ was taken from each fragment and the perpendicular diameters were measured, one being the longest and the other the shortest. The average diameter was considered the nuclear diameter of the hepatocyte. The nuclear volume was calculated from the formula: $\mathrm{V}=4 / 3 \pi \mathrm{R}^{3}$.

\section{Statistical analyses}

The results were analyzed by the Student $t$ test for independent samples. The differences were considered statistically significant for values of $\mathrm{p} \leq 0.05$.

\section{RESULTS}

The aspartate aminotransferase (AST), alanine aminotransferase (ALT) and alkaline phosphatase (ALP) activities were significantly higher in CBD rats than in the sham animals (Fig. 1).

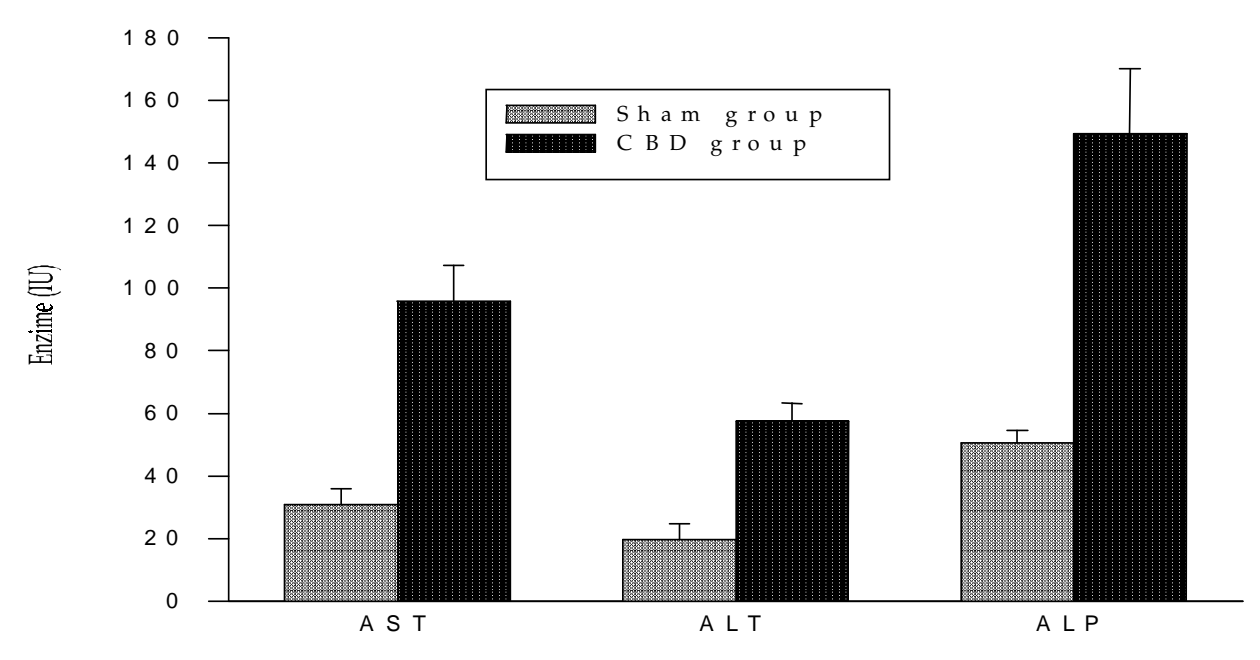

Figure 1 - Determination of the aspartate aminotransferase (AST), alanine aminotransferase (ALT) and alkaline phosphatase (ALP) activities. Each column represent the mean \pm standard deviation, $\mathrm{n}=30(\mathrm{p}<$ 0,001).

There was a significant reduction in the uptake of Tc-99m E.coli by the livers of the CBD rats when compared to the sham (Fig. 2). The data also show that there was a significant increase in the Tc-99m E.coli uptake by the lungs of the CBD rats. There was no significant difference in the uptake of Tc-99m E. coli by the spleens of the sham and CBD animals.
The histological examination of the liver slices from the sham animals did not present evident alterations. The hepatocytes had a normal architectural disposition, with the formation of well-constituted hepatic trabeculae (Figs. 3a and 4a). The hepatocytes exhibited rounded, regular nuclei (mean volume $=281 \mu \mathrm{m}^{3}$, Table 1 ). The histological examination of the liver slices from 
the CBD animals presented very evident alterations represented by: (1) an increase in the width of the periportal space, especially because of intense and diffuse proliferation of the bile ducts (Fig. $3 \mathrm{~b}$ ); (2) an accentuated polyploidy of the hepatocytes (mean volume $=: 843 \mu \mathrm{m}^{3}$, Table 1) with architectural disarrangement of the trabeculae and relatively frequent mitosis figures (Fig. 4 b).

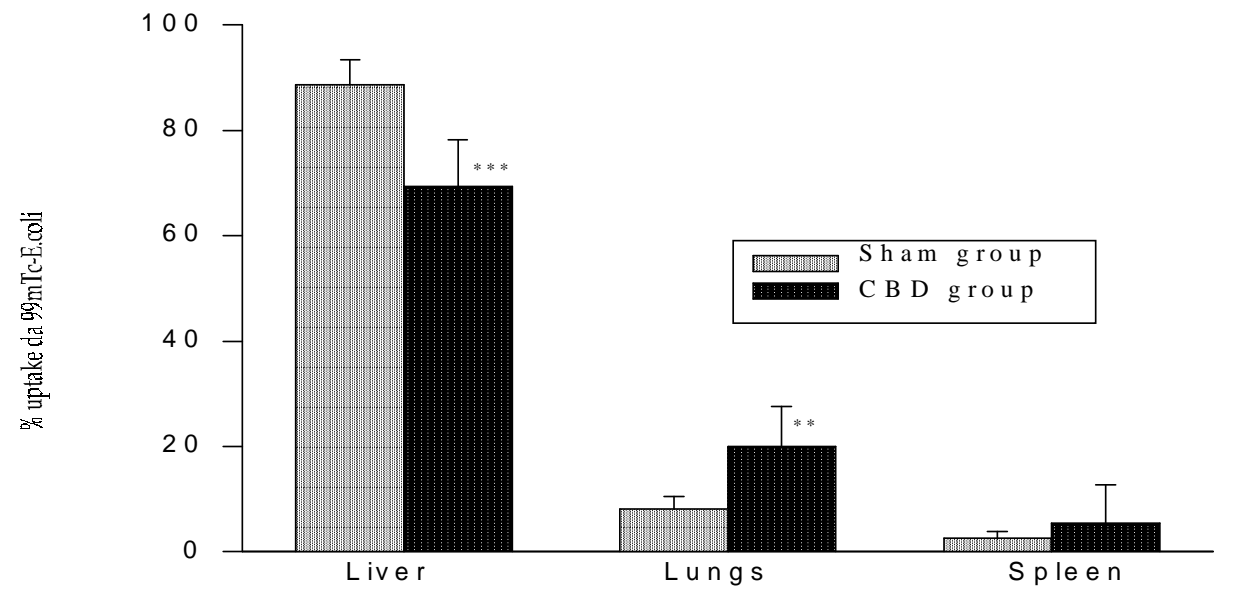

Figure 2 - Studies on the uptake of Tc-99 m E. coli by the liver, lungs and spleen of sham and CBD rats. Each column represents the mean \pm standard deviation $(\mathrm{n}=15)(* * \mathrm{p}<0.01)(* * * \mathrm{p}<0.001)$.
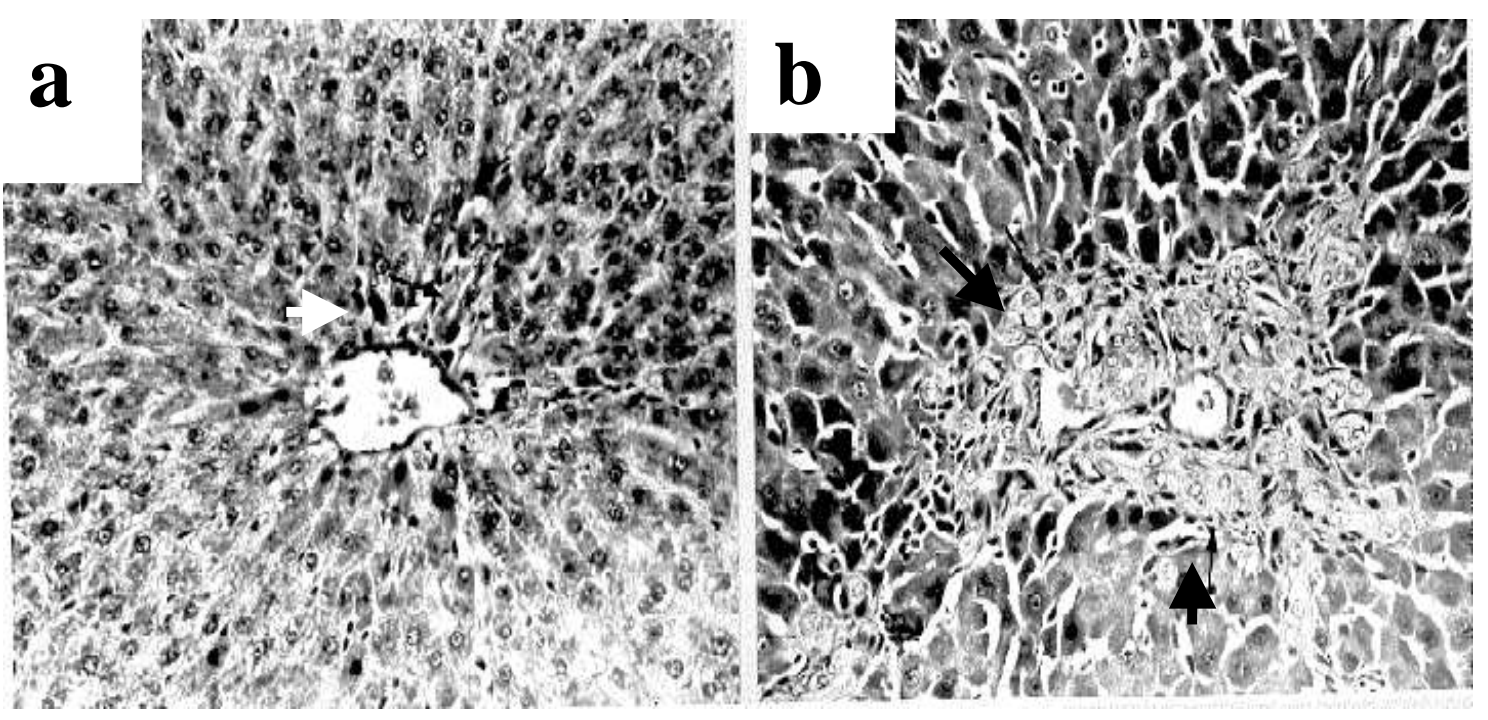

Figure 3 - Histological analysis of rat livers. (a) sham animal, simulated surgery, presenting a lobular architecture and a periportal space without histological alterations; (b) CBD animal seven days after obstruction of the common bile duct, presenting proliferation of the bile ducts (arrow) and, consequently, na increase in the periportal space, $\mathrm{HE}, 800 \mathrm{X}$. 

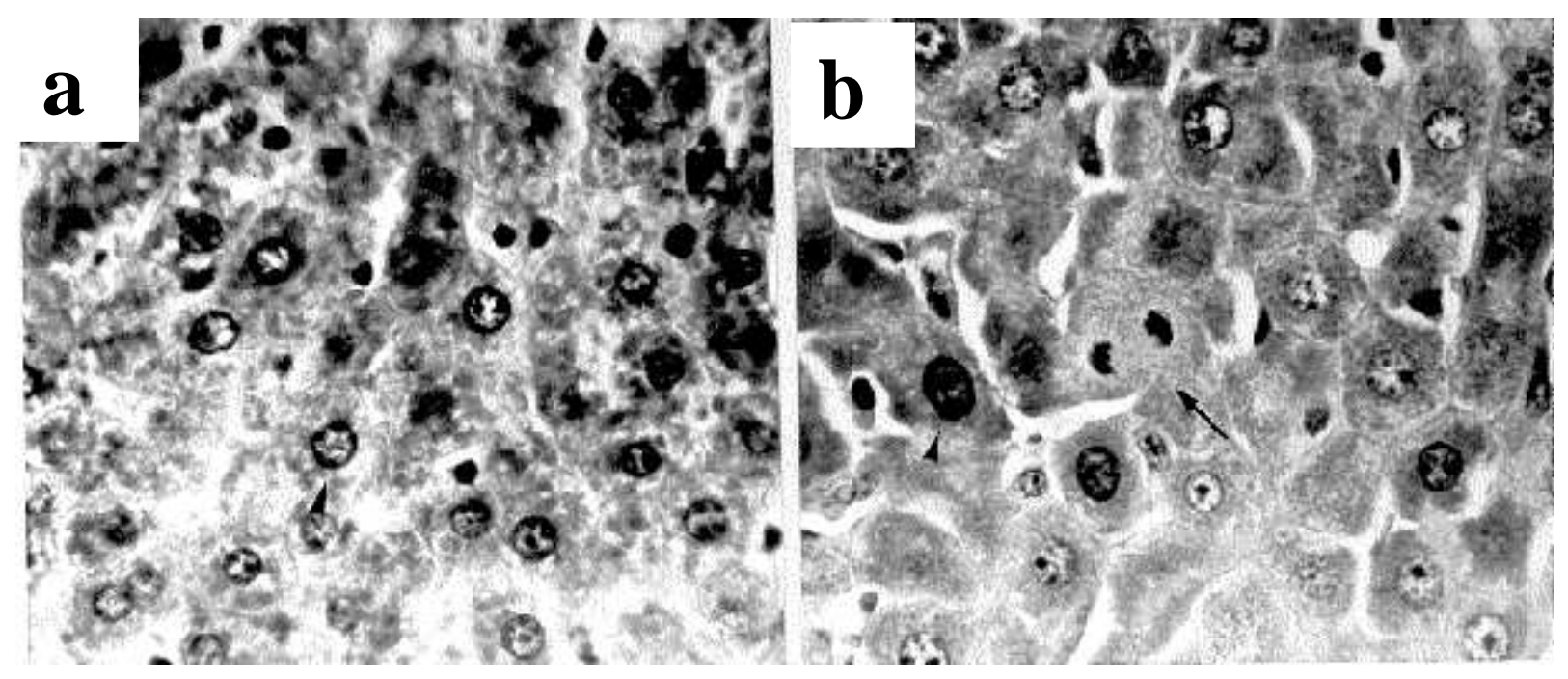

Figure 4 - Histological aspects of the rat livers. (a) sham animal, simulated surgery, presenting hepatocytes with nuclei of relatively uniform dimensions; (b) CBD animal seven days after ligature of the common bile duct, presenting hepatocytes with polyplóid nuclei (arrowhead) and mitosis figures (thin arrow). The Küpffer cells (thick arrow) were hypertrophic and hyperplasic in both animals, HE, $2000 \mathrm{X}$.

Table 1 - Mean nuclear volumes $\left(\mu \mathrm{m}^{3}\right)$ of hepatocytes

\begin{tabular}{lcccccc}
\hline Groups & $\mathbf{1}$ & $\mathbf{2}$ & $\mathbf{3}$ & $\mathbf{4}$ & $\mathbf{5}$ & $\mathbf{X} \pm$ SD \\
\hline Sham & 237 & 247 & 277 & 339 & 305 & $281 \pm 37$ \\
CBD & 799 & 1174 & 797 & 771 & 675 & $843 \pm 171^{* * *}$
\end{tabular}

The value expresses the mean nuclear volume of 30 nuclei for each rat. The mean nuclear volume $(\mathrm{x} \pm \mathrm{DP})$ for all the rats is also shown $(* * * \mathrm{p}<0,001)$.

The animals of the two groups presented focal areas with thickening of the alveolar septa of the lungs. There was no significant difference between them. The splenic parenchyma of the animals presented hyperplasic alterations of the lymphoid tissue in varying degrees of intensity. No important alterations in the Küpffer cells of the livers of the two groups of animals were observed. However, the Küpffer cells were hypertrophied and apparently hyperplasic in both groups of animals.

\section{DISCUSSION}

The experimental model of obstructive jaundice consisted in sectioning the common bile duct of the rats so that the bile did not reach the intestine, thus promoting a process of cholestasis. The aspartate aminotransferase (AST), alanine aminotransferase (ALT) and alkaline phosphatase (ALP) levels were significantly higher $(\mathrm{p}<0,001)$ in the serum of the CBD rats, indicating the occurrence of cellular lyses as a result of cholestasis. The increase in the alkaline phosphatase activity occurs principally in the obstructions of biliary tissue, while the AST and ALT enzymes may also assist in the diagnosis of hepatobiliary diseases (Sette et al., 1993; 
Zimmerman, 1995). The data obtained agree with the work of Ding et al. (1994) who observed higher levels of bilirubin and of AST, ALT and ALP in rats seven days after bile duct obstruction. The results of the evaluation of the mononuclear system in the present study showed that the livers of the CBD rats presented a significant reduction in Tc-99m E.coli uptake when compared to the sham animals. On the other hand, a significant increase uptake by the lungs was observed, while no significant difference between the two groups was observed for the spleen. This observation suggests that the functioning of the mononuclear phagocyte system was depressed. Considering that the Küpffer cells of the liver are usually effective in the removal of bacteria from the blood stream, the reduction in Tc-99m E.coli uptake by the liver may be an important factor in explaining the increase in susceptibility to infections observed in cases of biliar obstruction. Drivas et al. (1970) showed that patients with bile duct obstruction were more susceptible to post-operatory septic complications. They also observed that these complications could be attributed to the reduction in hepatic phagocitary function in approximately $50 \%$ of the patients. These results agree with those obtained by Tanaka et al. (1985). These researchers observed a significant reduction in colloidal ${ }^{99 \mathrm{~m}} \mathrm{Tc}$-sulfide uptake by the liver of rats seven days after ligature of the common bile duct. The histological examination of the liver slices presented an increase in the thickness of the periportal space and intense polyploidy with a predominance of large nuclei. These data indicate that degenerative lesions and necrosis of the hepatocytes occurred in the liver, an observation that demonstrated the occurrence of hepatic parenchyma (Bogliolo, 1987). Thus, it is possible that the lesions observed in the hepatocytes and the bile ducts may compromise in some way the hepatic function, decreasing, for example, the phagocitary capacity of the Küpffer cells.

No significant difference relative to the sham animals was observed in the Tc-99mE.coli uptake by the spleens of the CBD rats. The same result has been observed in earlier studies employing bacteria labeled with radioactive isotopes (Megison et al., 1991; Ding et al., 1994).

The lungs of the CBD rats showed an increased uptake of Tc-99m E.coli relative to the sham group. These results agree with those presented by Holmberg et al. (1986) who observed and increase in the uptake of colloidal ${ }^{99}$ tecnetium sulfide $\left({ }^{99 \mathrm{~m}} \mathrm{Tc}_{2} \mathrm{~S}_{7}\right)$ by the lungs of jaundiced rats seven days after ligature of the common bile duct.

The histological examination of the lung slices did not show any significant differences between the CBD and sham groups. Contrary to what was observed with the livers, the pulmonary parenchyma was preserved. Therefore, the lungs were able to exercise a compensatory mechanism, i.e., they were able to increase uptake of Tc-99m E.coli due the reduction of phagocitary capacity of liver. This hypothesis was also advanced by Katz et al. (1984) who observed the same phenomenon. However, those researchers showed that, although the lungs were efficient uptake of bacteria, the capacity to kill the sequestered bacteria was very reduced. The permanence of viable bacteria in the lungs could result in their return to the systemic circulation, configuring a potent mechanism for predisposition to septicemia, endotoxemia and pulmonary failure. The reduction in the hepatic phagocitary capacity associated with the increase in phagocytosis of Tc-99m E.coli by the lungs could contribute to a better understanding of the mechanisms involved in cases of bacteremia, renal failure and pulmonary dysfunction observed in clinical analyses of obstructive jaundice.

\section{ACKNOWLEDGEMENTS}

The authors thank FAPEMIG for the financial support.

\section{RESUMO}

Nos pacientes com obstrução do ducto biliar, as infecções e a endotoxemia continuam sendo uma das principais causas de morbidade e mortalidade. $\mathrm{O}$ objetivo desse trabalho foi investigar a capacidade fagocitária do sistema mononuclear, em um modelo experimental de icterícia obstrutiva, utilizando Tc-99m E.coli. Os níveis de aspartato aminotransferase (AST), alanina aminotransferase (ALT) e fosfatase alcalina (PAL) nos ratos com ligadura do ducto biliar comum (CBD) encontram-se significativamente mais elevados do que nos ratos sham. $(\mathrm{p}<0.001)$. O fígado dos animais ictéricos apresentou uma significativa redução na captação da Tc-99m E.coli quando comparado com o controle. 
Os dados mostraram também, que houve um aumento significativo na captação da Tc-99m E.coli pelo pulmão dos ratos ictéricos ( $\mathrm{p}<$ 0.01). O exame histológico dos cortes de fígado dos animais ictéricos apresentou proliferação intensa e difusa dos ductos biliares e uma acentuada poliploidia dos hepatócitos (volume médio: $843 \mu \mathrm{m}^{3}$ ), Não foram observadas alterações significativas nos pulmões de nenhum grupo.

\section{REFERENCES}

Athlin, L.; Holmberg, S. B. and Hafstrom, L. (1991) Macrophage function and surgery. Eur. J. Surg., 157, 163-170.

Barbosa, A. J. A. (1978), Estudo morfológico, quantitativo e citométrico dos neurônios do plexo mientérico, em condições de hipertrofia experimental das túnicas musculares do cólon. Tese (Doutorado), Faculdade de Medicina, UFMG, Belo Horizonte, Brasil.

Bogliolo, L. (1987), Fígado e Vias Biliares. In: Lopes,E. R.; Chapadeiro, E.; Raso, P. and Tafuri, W. L. Bogliolo Patologia. $4^{\text {th }}$ ed. Rio de Janeiro : Guanabara Koogan. pp. 546-614.

Ding, J. W.; Andersson, R.; Soltesz, V.; Willén, R. and Bengmark, S. (1994), Obstructive jaundice impairs reticuloendothelial function and promotes bacterial translocation in the rat. J. Surg. Res., 57, 238-245.

Diniz, S. O. F.; Resende B. M.; Nunan E. A.; Simal, C. J. R. and Cardoso, V. N. (1999), ${ }^{99 m}$ Technetium labelled Escherichia coli. Appl Radiat Isot, 51, 33-6.

Drivas, G.; James, O. and Wardle, N. (1976), Study of reticuloendothelial phagocytic capacity in patients with cholestasis. Br. Med. J., 1, 1568-1569.

Guyton, A. C. and Hall, J. E. (2002), Tratado de fisiologia médica. Rio de Janeiro : GuanabaraKoogan.

Holmberg, J. T.; Bergqvist, L.; Hultberg, B.; Hagerstrand, I.; Ihse, I. and Rydén, S. (1986), Radiolabelled colloid uptake distribution and pulmonary contents and localization of lysosomal enzymes in cholestatic rats. Scand. J. Gastroenterol., 21, 291-299.

Katz, S.; Grosfeld, J. L.; Gross, K.; Plager, D. A.; Ross, D.; Rosenthal, R. S.; Hull, M. and Weber, T. R. (1984), Impaired bacterial clearance and trapping in obstructive jaundice. Ann. Surg., 199, 14-20.

Megison, S. M.; Dunn, C. W.; Horton, J. W. and Chao, H. (1991), Effects of relief of biliary obstruction on mononuclear phagocyte system function and cell mediated immunity. Br. J. Surg., 78, 568-571.
Sette, H. J.; Neto, E. P. A. L.; Barros, M. F. A.; Sette, M. J. A.; Purceli, E. L.; Pessoa, M. G.; Pandullo, F.; Renato, A. C. (1993), Estudo do paciente com patologia hepatobiliar. In: Dani, R. and Castro, L. P. Gastroenterologia clínica. $3^{\text {rd }}$ ed. Rio de Janeiro : Guanabara-Koogan. pp. 1121-1131.

Tanaka, N.; Ryden, L.; Bergqvist, L.; Christensen, P. and Bengmark, S. (1985), Reticulo-endothelial function in rats with obstructive jundice. Br.J. Surg., 72, 946-949.

Tanner, A. R.; Arthur, M. O. P. and Wright, R. (1984), Macrophage activation, chronic inflammation and gastrointestinal disease. Gut, 25, 760-783.

Zimmerman, H. J. (1995), Avaliação das funções e da integridade do fígado. In: Henry, J. B. Diagnósticos clínicos and tratamento por métodos laboratoriais. $18^{\text {th }}$ ed. Rio de Janeiro : Mande. pp. 341-386.

Received: July 04, 2005; Revised: July 14, 2005; Accepted: August 01, 2005. 